\title{
Hygienic Practices and Bacteriological Quality of Cow Raw Milk from Selected Smallholder Dairy Farms of Mersa Town, North Wollo, Ethiopia
}

\author{
Ebrahim Oumer ${ }^{1}$, Solomon Tsegaye ${ }^{2}$, Ashenafi Damtew ${ }^{2}$ and Aklilu Feleke ${ }^{*}$ \\ ${ }^{1}$ Mersa Agricultural TVET College, Woldya, Ethiopia \\ ${ }^{2}$ Woldia University, College of Agriculture, Mersa, Ethiopia \\ ${ }^{3}$ Addis Ababa University, College of Veterinary Medicine and Agriculture, Ethiopia
}

Corresponding author: Aklilu Feleke, Addis Ababa University, College of Veterinary Medicine and Agriculture, Ethiopia, Tel: +251 111239752 ; Email: ataklilu@yahoo.com

Received Date: July 18, 2017; Accepted Date: August 07, 2017; Published Date: August 17, 2017

Copyright: (C2017 Oumer E, et al. This is an open-access article distributed under the terms of the Creative Commons Attribution License, which permits unrestricted use, distribution, and reproduction in any medium, provided the original author and source are credited.

Citation: Oumer E, Tsegaye S, Damtew A, Feleke A (2017) Hygienic Practices and Bacteriological Quality of Cow Raw Milk from Selected Smallholder Dairy Farms of Mersa Town, North Wollo, Ethiopia. Eur Exp Biol. Vol. 7 No. 4:22

\section{Abstract}

The present cross sectional study was conducted to assess hygienic practices and determination of bacterial load of milk when directly milked from the udder and from the collecting bucket at the farm level in selected smallholder of Mersa town; from November 2016 to May 2017. A total of 120 respondents were interviewed and 60 milk samples were collected for laboratory analysis to assess bacterial load. Aerobic mesophilic bacterial counts (AMBC) and coliform counts (CC) were conducted on milk samples. Results showed that, majority of small-dairy holders were males, managing their cattle in unclean environments and practicing extensive grazing system on communal grazing area. The mean aerobic mesophilic bacterial counts of raw milk samples analyzed were $5.81 \log _{10} \mathrm{cfu} / \mathrm{ml}$ (udder), 8.01 $\log _{10} \mathrm{cfu} / \mathrm{ml}$ (bucket) The mean coliform counts were 3.7 $\log _{10} \mathrm{cfu} / \mathrm{ml}$ (udder), $5.15 \log _{10} \mathrm{cfu} / \mathrm{ml}$ (bucket) and the increment of both counts at the milk bucket was observed statistically significant $(\mathrm{P}=0.000)$ and there was no significant variation between kebeles $(P=0.921)$ for aerobic mesophilic bacterial counts and $(P=0.715)$ for coliform count. According to international standards of raw milk quality, both of the above counts found to have values above the upper limits. Milk produced by the selected small-holder dairy cow owners in Mersa town were of poor quality and can be a potential source of milk-borne infections.

Keywords: Aerobic mesophilic bacterial counts; Milk; Colony counts; Milk bucket; Mersa

\section{Introduction}

Milk is a sterile fluid when secreted into alveoli of udder; however, after secretion microbial contamination could occur from the udder itself, external part of the udder and from the surface of milk handling and storage equipment, and also the air, soil, feed, grass and feces are also possible sources of contamination [1]. The demand of for safe and high quality milk by consumers has placed responsibility on producers, retailers and manufacturers to produce safe and good quality milk and milk products.

Milk and milk products have a high value in feeding the population in both rural and urban areas. Wholesome milk and milk products have refreshing, potable, economical and nutritious food for human being [2]. It is a cash crop in the milk shed areas that allow families to purchase other food stuffs. Raw or processed milk is a very suitable growth medium for the growth of several microorganisms because of its essential nutrients, high water content and nearly neutral $\mathrm{pH}$. The cow health status and its environment, uncleaned and non-sanitized milking equipment, and unhygienic milk workers could serve as sources of contamination.

The safety of products in dairy industry regarding to foodborne diseases is a great concern around the world. This is a major concern especially in developing countries where production is generally unhygienic [3]. A range of bacteria could be isolated from a raw cow's milk such as S. aureus, Salmonella $s p$., Acinetobacter sp., Lactobacillus sp., Corynebacterium sp., Streptococcus sp., Coliforms, E. coli, Klebsiella sp., Bacillus subtilis, Listeria sp., Lactobacillus sp., Enterobacter sp., Pseudomonas sp., and Flavibacterium species.

Ethiopia as one of the developing countries, dairy production constitutes an important part of the agricultural production system. A rapidly increasing the country population together with fast urbanization creates an increased production demand for milk and milk products $[4,5]$. Even though milk placed in an important role in the nutrition of consumers and as an income of producers, there is limitation in information undertaken on the assessment of bacteriological quality of raw cow milk in northern Ethiopia in general and in Mersa in particular. 


\section{Objectives}

- To assess the hygienic practice from smallholder dairy farmers in kebeles of Mersa town;

- To assess the bacterial load of raw milk collected from dairy cows and milking utensils from selected smallholder farms.

\section{Materials and Methods}

\section{Study area}

The study was conducted in Mersa located in Habru district, North Wollo administrative zone of the Amhara region, Ethiopia. Meresa is located at $\mathbf{4 9 0}$ kilo meters North of Addis Ababa and 90 kilo meters North of Dessie town and the main road from Addis Ababa crosses the town. Mersa is located at latitude of $11^{\circ} 35^{\prime} \mathrm{N}$, longitude of $39^{\circ} 38^{\prime} \mathrm{E}$ and an elevation of 1557 m.a.s.l. The town land coverage is 2002.95 hectare and the average altitude ranges from 1200 to 2350 m.a.s.l. Habru district is classified under moist warm climatic zone $[6,7]$. The mean annual rainfall is $1090 \mathrm{~mm}$. The mean minimum and maximum daily temperature ranges from $13.27^{\circ} \mathrm{C}$ to $28.96^{\circ} \mathrm{C}$ with an average of $21.12^{\circ} \mathrm{C}$

\section{Study design}

A cross sectional study was conducted from November 2016May 2017 to assess hygienic practices and determination of bacterial load of milk at the farm level in selected smallholder dairy farms of Mersa town. North Wollo, Ethiopia.

\section{Study population}

The study animals were lactating cross breed cows (Holstein Frisian $\mathrm{X}$ indigenous Zebu and and indigenous zebu) from smallholder dairy farmers in the Mersa kebele 02, Abyiot fre and Woldiyia Kurkura.

\section{Sample size and sampling method}

Forty milk samples from 40 lactating cows from 33 small holder dairy farms and 20 milk samples from milking buckets of 20 small holder dairy farms were taken aseptically. For the questionnaire survey 120 animal owners and attendants were interviewed. Mersa town has two urban and four rural kebels among which Mersa kebele 02, Abyote fre and Woldyia kurkura were selected using simple random sampling method [8]. From the three kebeles selected 40 lactating cows and 20 milking utensils were sampled from smallholder farms selected conveniently based on topographical accessibility. For the questionnaire survey, the total number of respondents who were interviewed during the data collection period in this study was 120 individuals which were selected conveniently based on topographical accessibility [9].

\section{Questionnaire survey}

Semi-structured questionnaires were used to assess the hygienic practices of dairy farms. Also, the questionnaire was used to collect information on risk factors for bacterial contaminations in milk. Sanitary conditions of milking environment, hygiene of cows' udder and milk handlers, hygienic status of milking equipment and their awareness on zoonotic diseases were major factors considered.

\section{Bacteriological Analysis}

\section{Sample collection and transportation}

Milk samples from the four quarters were collected in labeled sterile glass bottles from each of the four quarters, as well as from milking utensils were also collected in sterile glass bottles [10]. The milk samples were transported in an ice box to Veterinary Microbiology Department of Kombolcha Regional Animal Health Laboratory for analysis. The samples were stored at $+4^{\circ} \mathrm{C}$ until processed and analyzed next day.

\section{Quantitative analysis of raw milk for bacteria}

Dilution and culturing milk samples: According to American Public Health Association (1992) The dilution peptone water was labeled with sample number and dilution number one $\mathrm{ml}$ of the milk sample was added to dilution blanks and serially diluted up to $10^{-6}$ for milk samples taken from the milking bucket and up to $10^{-4}$ for milk samples taken from the cows' udder by taking one $\mathrm{ml}$ to the next dilution bottle after mixing. One $\mathrm{ml}$ was discarded from the last dilution [11]. After thorough mixing, to place appropriate dilutions on petridishes the cover of petri-dishes was lifted just high enough to insert pipettes two plates inoculated per dilution. About $10-15 \mathrm{ml}$ of the melted plate count agar and Maconkey agar for SPC and coliform count, respectively, were poured in to each plate by lifting gently the cover of the petri-dish just enough to pour the medium [12]. The medium was gently mixed with the test portions in the petridishes by rotating and tilting after the mixture was evenly spread over the bottom of plate; it was allowed to solidify on a level surface. The plates were then inverted and placed in an incubator at $37^{\circ} \mathrm{C}$ for 48 hours. Incubating control plates for each sterilization, lots of dilution blanks and medium were used to check sterility of the dilution water and medium.

\section{Standard plate count (SPC)}

One $\mathrm{ml}$ from each sample of raw milk was transferred to $9 \mathrm{ml}$ sterile $0.1 \%$ peptone water and thoroughly mixed to give $1: 10$ dilution. Serial dilutions were made by transferring $1 \mathrm{ml}$ of the previous dilution in $9 \mathrm{ml}$ of sterile peptone water. Sample from each dilution level was cultured by a glass spread method to the standard plate count agar (Oxoid, England) [13]. Total Bacterial Count was made by incubating cultured dilutions of milk samples on Plate Count Agar (Oxoid, England) plates. Colonies were counted after the culture media was incubated at $37^{\circ} \mathrm{C}$ for 48 hours. Total number of colonies on plates 30 to 300 per plates was selected and colonies were counted.

\section{Reading and interpretation of results}

According to American Public Health Association, Standard plate counts SPC after incubation at $37^{\circ} \mathrm{C}$ for 48 hours all colonies including those pin point size were counted on selected 
plates. Results from plates which contained 30 to 300 colonies per plate were recorded [14]. If a plate from the two consecutive decimal dilutions yields colony counts of 30 to 300 the counts for each dilution were computed by the following formula.

Where $\mathrm{N}$ =number of colonies per mile-liter of milk; $\mathrm{n}_{2}=$ number of plates in next higher dilution counted; $\mathrm{n}_{1}=$ number of plates on lower dilution counted

When plates counts less than 30 colonies, the results were read as less than 30 times the reciprocal of the dilution number. If more than 300 colonies developed in the highest dilution plates, the counts was recorded as more than 300 times the reciprocals of dilution.

Coliform count (CC) for milk after incubation of the plate at $32^{\circ} \mathrm{C}$ for 48 hours purplish red colonies with bile precipitation around them were counted as coliforms from MacConkey agar results from only those plates, which contained between 15 and 150 colonies were recorded interpretation were similar with that of SPC.

\section{Data collection, management and analysis}

Descriptive statics such as mean, proportions, standard deviations and a 95\% confidence interval were performed. Standard plate count and coliform count were counted as cfus per $\mathrm{ml}$ the values were transformed in to $\log _{10} \mathrm{cfu} / \mathrm{ml}$ to normalize the data [15]. The difference the bacterial load between the milk samples from the lactating cows and milking utensils were analyzed using paired t-test. A P-value of $<0.05$ was considered indicative of a statistically significant difference.

\section{Results}

Determination of bacterial load of milk samples through standard plate and coliform counts ( $\log _{10}$ $\mathrm{CFU} / \mathrm{ml}$

There was an increase in both $\mathrm{CC}$ and $\mathrm{AMBC}$ for milk samples taken from the milking bucket (Table 1).

Table 1: Mean values for total SPC and coliform count (Log10 $\mathrm{CFU} / \mathrm{ml}$ ) from lactating cows and milking bucket in the study areas, 2017.

\begin{tabular}{|l|l|l|l|l|}
\hline Variables & Mean & N & $\begin{array}{l}\text { Std. } \\
\text { Deviatio } \\
\mathbf{n}\end{array}$ & $\begin{array}{l}\text { Std. Error } \\
\text { Mean }\end{array}$ \\
\hline Standard plate count & \multicolumn{4}{|l}{} \\
\hline For milking bucket & 8.0185 & 20 & 0.1124 & 0.02513 \\
\hline For cows & 5.8334 & 40 & 0.06641 & 0.01485 \\
\hline Coliform count & & & & \\
\hline For milking bucket & 5.154 & 20 & 0.03243 & 0.00725 \\
\hline For cows & 3.7068 & 40 & 0.07885 & 0.02057 \\
\hline
\end{tabular}

Table 2: Results of t-test for total aerobic mesophilic bacteria and coliform count from lactating cows and milking bucket in the study areas.

\begin{tabular}{|c|c|c|c|c|c|c|c|c|}
\hline \multirow{3}{*}{ Variables } & \multicolumn{5}{|c|}{ Paired differences } & \multirow[t]{3}{*}{ t-value } & \multirow[t]{3}{*}{ df } & \multirow[t]{3}{*}{ P-value } \\
\hline & \multirow{2}{*}{ Mean } & \multirow{2}{*}{ Std deviation } & \multirow{2}{*}{$\begin{array}{ll}\text { Std } & \text { error } \\
\text { mean } & \end{array}$} & \multicolumn{2}{|l|}{$95 \% \mathrm{Cl}$} & & & \\
\hline & & & & Lower & Upper & & & \\
\hline Standard plate count & 2.18315 & 0.12862 & 0.02876 & 2.12295 & 2.4335 & 75.907 & 19 & 0.001 \\
\hline Coliform count & 1.44719 & 0.09585 & 0.2143 & 1.40233 & 1.49209 & 67.519 & 19 & 0.001 \\
\hline
\end{tabular}

Bi-variate analyses involving $\mathrm{AMBC}$ and coliform count of milk samples collected from lactating cows and milking buckets were performed by using paired t-test. Statistically significant differences were observed between total aerobic mesophilic as well as coliform count in milk samples taken from lactating cows and milking bucket (container) (Table 2).

Analysis of variance indicted that there is no significant difference in both $\mathrm{AMBC}$ and coliform count among the kebeles (Table 3).

Table 3: Mean ( \pm S.E.) aerobic mesophilic bacterial and coliform count of milk sample $\left(\log _{10} \mathrm{cfu} / \mathrm{ml}\right)$ in the study area.

\begin{tabular}{|l|l|l|}
\hline \multirow{2}{*}{ Kebeles } & \multicolumn{2}{|l|}{ Critical points of sampling } \\
\cline { 2 - 3 } & AMBC & Coliforms \\
\hline
\end{tabular}

\begin{tabular}{|l|l|l|l|l|}
\hline & Udder & Bucket & Udder & Bucket \\
\hline $\begin{array}{l}\text { Mersa } \\
\text { kebele }\end{array}$ & $5.83 \pm 0.17$ & $8.04 \pm 0.05$ & $\begin{array}{l}3.70 \\
0.025\end{array}$ & $5.16 \pm 0.005$ \\
\hline Abiyot fre & $5.86 \pm 0.19$ & $8 \pm 0.04$ & $3.73 \pm 0.02$ & $5.15 \pm 0.014$ \\
\hline $\begin{array}{l}\text { Woldia } \\
\text { kurkura }\end{array}$ & $5.95 \pm 0.31$ & $7.98 \pm 0.29$ & $3.73 \pm 0.05$ & $5.13 \pm 0.017$ \\
\hline
\end{tabular}

Dairy cattle housing and cleaning practices of the study population

The following table describes types of housing, cleaning practice and calf management in the study areas (Table 4).

Table 4: Types of housing, cleaning practice and calf management in the study areas $(\mathrm{N}=120)$. 


\begin{tabular}{|c|c|c|c|c|}
\hline \multirow{2}{*}{ Variables } & \multicolumn{3}{|l|}{ Study area } & \multirow{2}{*}{$\begin{array}{l}\text { Overall } \\
(\mathrm{N}=120)\end{array}$} \\
\hline & $\begin{array}{l}\text { Merasakebele } \\
02(n=40)\end{array}$ & $\begin{array}{l}\text { Abiyotfrie } \\
(n=40)\end{array}$ & $\begin{array}{l}\text { Woldia } \\
\text { Kurkura } \\
(n=40)\end{array}$ & \\
\hline \multicolumn{5}{|l|}{ Barn types } \\
\hline $\begin{array}{l}\text { Concrete } \\
\text { floor }\end{array}$ & $12.5 \%(5)$ & $7.5 \%(3)$ & $10 \%(4)$ & $10 \%(12)$ \\
\hline Earthen & $87.5 \%(35)$ & $92.5 \%(37)$ & $90 \%(36)$ & $\begin{array}{l}90 \% \\
(108)\end{array}$ \\
\hline \multicolumn{5}{|c|}{ Barn floor bedding types } \\
\hline $\begin{array}{l}\text { Grass } \\
\text { bedding }\end{array}$ & $35 \%(14)$ & $30 \%(12)$ & $15 \%(6)$ & $\begin{array}{l}26.7 \% \\
(32)\end{array}$ \\
\hline $\begin{array}{l}\text { Muddy } \\
\text { bedding }\end{array}$ & $65 \%(26)$ & $70 \%(28)$ & $85 \%(34)$ & $\begin{array}{l}73.3 \% \\
(88)\end{array}$ \\
\hline
\end{tabular}

\begin{tabular}{|l|c|c|c|l|}
\hline Daily & $62.5 \%(25)$ & $55 \%(22)$ & $32.5 \%(13)$ & $50 \%(60)$ \\
\hline $\begin{array}{l}3 \text { times a } \\
\text { week }\end{array}$ & $37.5 \%(15)$ & $45 \%(18)$ & $67.5 \%(27)$ & $50 \%(60)$ \\
\hline Calf management & $55 \%(22)$ & $12.5 \%(5)$ & $57.5 \%(23)$ & $\begin{array}{l}41.7 \% \\
(50)\end{array}$ \\
\hline Clean body & $45 \%(18)$ & $87.5 \%(35)$ & $42.5 \%(17)$ & $\begin{array}{l}58.3 \% \\
(70)\end{array}$ \\
\hline Soiled body & & & \\
\hline
\end{tabular}

\section{Feeding and watering practices}

Feeding regimen and source of water for farming activity was assessed in the questionnaire survey and results show that much of the farms uses river water for their farm activities and their animals on natural pasture (Table 5).

Barn cleaning frequency

Table 5: Categorization of respondents' based on feeding regimen and sources of water in the study area, $2017(\mathrm{~N}=120)$.

\begin{tabular}{|l|l|l|l|l|}
\hline \multirow{2}{*}{ Variables } & \multicolumn{2}{|l|}{ Study area } & Overall (N=120) \\
\cline { 2 - 5 } & Merasakebele 02 (n=40) & Abiyotfrie (n=40) & WoldiaKurkura (n=40) & \\
\hline Feeding regimen & $55 \%(22)$ & $70 \%(28)$ & $65 \%(26)$ & $63.3 \%(76)$ \\
\hline Grazing natural pasture & $25 \%(10)$ & $20 \%(8)$ & $17.5 \%(7)$ & $20.8 \%(25)$ \\
\hline Supplemented with local feed & $10 \%(4)$ & $5 \%(2)$ & $12.5 \%(5)$ & $9.2 \%(11)$ \\
\hline Supplemented with concentrate & $4(10 \%)$ & $2(5 \%)$ & $5 \%(2)$ & $6.7 \%(8)$ \\
\hline Mixed & & $5 \%(3)$ & $12.5 \%(5)$ & $15 \%(18)$ \\
\hline Sources of water for farm activities & $25 \%(10)$ & $80 \%(32)$ & $80 \%(32)$ & $73.3 \%(88)$ \\
\hline Pipe & $60 \%(24)$ & $12.5 \%(5)$ & $5 \%(3)$ & $11.7 \%(14)$ \\
\hline River & $15 \%(6)$ & & \\
\hline Deep wells & & & \\
\hline
\end{tabular}

Practices towards milking and hygienic condition of respondents'

Participants of this study were also asked about the hygienic practices they follow in the process of milk production (Table 6).

Table 6: Milking and hygienic practices followed by producers in the study areas, 2017 ( $N=120)$.

\begin{tabular}{|c|c|c|c|c|c|}
\hline \multirow{2}{*}{\multicolumn{2}{|c|}{ Variables }} & \multicolumn{3}{|l|}{ Study area } & \multirow[t]{2}{*}{ Overall $(\mathrm{N}=120)$} \\
\hline & & Merasakebele $02(n=40)$ & Abiyotfrie $(n=40)$ & WoldiaKurkura $(n=40)$ & \\
\hline \multicolumn{6}{|c|}{ Milking frequency } \\
\hline & Twice a day & $87.5 \%(35)$ & $92.5 \%(37)$ & $95 \%(38)$ & $81.7 \%(110)$ \\
\hline & 3 times a day & $12.5 \%(5)$ & $7.5 \%(3)$ & $5 \%(2)$ & $8.3 \%(10)$ \\
\hline \multicolumn{6}{|c|}{ Milking utensils used for milking } \\
\hline & Plastic & $90 \%(36)$ & $87.5 \%(35)$ & $75 \%(30)$ & $84 \%(101)$ \\
\hline & Pot & $10 \%(4)$ & $12.5 \%(5)$ & $25 \%(10)$ & $16 \%(19)$ \\
\hline
\end{tabular}




\begin{tabular}{|l|l|l|l|l|l|l|}
\hline & Daily & $95 \%(38)$ & $35 \%(16)$ & $80 \%(32)$ & $70 \%(84)$ \\
\cline { 2 - 6 } & 3 times a week & $5 \%(2)$ & $65 \%(26)$ & $20 \%(8)$ & $30 \%(36)$ \\
\hline $\begin{array}{l}\text { Udder washing } \\
\text { before milking }\end{array}$ & Yes & $35 \%(14)$ & $47.5 \%(19)$ & $55 \%(22)$ & $45.8 \%(55)$ \\
\cline { 2 - 6 } & No & $65 \%(26)$ & $52.5 \%(21)$ & $45 \%(18)$ & $54.2 \%(65)$ \\
\hline \multirow{2}{*}{ Hand washing practice before milking } & $45 \%(18)$ & $35 \%(14)$ & $27.5 \%(11)$ & $35.8 \%(43)$ \\
\hline \multirow{2}{*}{ Teat (udder) drying habit or practice before washing } & $55 \%(22)$ & $65 \%(26)$ & $72.5 \%(29)$ & $64.2 \%(77)$ \\
\hline & Yes & $40 \%(16)$ & $30 \%(12)$ & $35 \%(14)$ & $35 \%(42)$ \\
\hline
\end{tabular}

\section{Respondents' knowledge towards public health aspect}

The participants of this study were also asked about their knowledge on public health issues associated with consumption of raw milk and their history regarding whether they suffer from diseases associated with consumption of raw milk (Table 7).

Table 7: Categorization of respondents' knowledge on public health aspect of raw milk consumption in the study areas, 2017 $(N=120)$.

\begin{tabular}{|c|c|c|c|c|}
\hline \multirow{2}{*}{$\begin{array}{l}\text { Variable } \\
\text { s }\end{array}$} & \multicolumn{3}{|l|}{ Study areas } & \multirow{2}{*}{$\begin{array}{l}\text { Overall } \\
(\mathrm{N}=120)\end{array}$} \\
\hline & $\begin{array}{l}\text { Merasakebel } \\
\text { e } 02(n=40)\end{array}$ & $\begin{array}{l}\text { Abiyotfrie } \\
(n=40)\end{array}$ & $\begin{array}{l}\text { WoldiaKurkur } \\
\text { a }(n=40)\end{array}$ & \\
\hline \multicolumn{5}{|c|}{ Habit of milk consumption } \\
\hline Raw & $30 \%(12)$ & $\begin{array}{l}57.5 \% \\
(23)\end{array}$ & $60 \%(24)$ & $49.1 \%(59)$ \\
\hline Boiled & $70 \%(28)$ & $\begin{array}{l}42.5 \% \\
(17)\end{array}$ & $40 \%(16)$ & $50.9 \%(61)$ \\
\hline \multicolumn{5}{|c|}{ Knowledge of risk associated with consumption of raw milk } \\
\hline Yes & $55 \%(22)$ & $\begin{array}{l}42.5 \% \\
(17)\end{array}$ & $32.5 \%(13)$ & $44 \%(52)$ \\
\hline No & $45 \%(18)$ & $\begin{array}{l}57.5 \% \\
(23)\end{array}$ & $67.5 \%(27)$ & $56 \%(68)$ \\
\hline \multicolumn{5}{|c|}{ Experience of suffering from food borne infection } \\
\hline Yes & $32.5 \%(13)$ & $45 \%(18)$ & $55 \%(22)$ & $44.1 \%(53)$ \\
\hline No & $67.5 \%(27)$ & $55 \%(22)$ & $45 \%(18)$ & $55.9 \%(67)$ \\
\hline
\end{tabular}

\section{Discussion}

The present study shows that type of animal house floor, insufficiently cleaning or washing of hands and udder immediately before milking, source and quality of water used for cleanliness (hands and milk equipment's), type of storage containers used and milk storage duration play an important role in the microbial contamination of raw milk. The current study further indicates that there is a consumption habit of raw milk and milk products by small-holder dairy farmers [16-18].
On top of this, low dairy house cleaning practices as well as dirty environments, and also milkers poor personal hygiene in most smallholder dairy farmers, have implications on sources of pathogens for mastitis and other diseases $[19,20]$. The finding of this study is in line with the previous reports by Bukuku, Shija, Mesfin and Bethlehem and Shemeles in Arusha, Tanga, Sidama, and Gondar, respectively. In the study, there is no proper concrete drainage system that make cleaning of the farms very difficult and increases the probability of microbial contamination of milk which is in agreement with the reports by Yoseph et al., Yitaye et al. and Mesfin [20-22].

All the smallholder dairy farms in the study area uses hand milking in which milking is done without washing of hands before milking and between milking of different dairy cows in the same barn and probably increase microbial contamination of milk. Similar reports were done by Swai and Schoonman [23] and Shija [24] in the Tanga region of Tanzania. Most dairy farm owners in the present study do not sufficiently perform cleaning of cow's udder and teat with potable water and do not dry it properly. However, it is important since cow's udder and teat could have direct contact with the ground, urine, dung and feed refusals while resting, and this contributes the possible contamination of milk. The current study is in agreement with the report of Derese. Contrary to this study, Haile et al. reported that $82.5 \%$ of the small size farms owning households in Hawassa city are practicing pre milking udder washing.

In the current study higher $\mathrm{AMBC}$ mean value from samples taken directly from the udder $\left(5.83 \log _{10} \mathrm{cfu} / \mathrm{ml}\right)$ was obtained as compared to the report of Mogessie and Fekadu in Hawassa College of Agriculture dairy farm [3 to $4 \log _{10} \mathrm{cfu} / \mathrm{ml}$ ] and Haile et al. in Hawassa [4.57 $\log _{10} \mathrm{cfu} / \mathrm{ml}$ ]. The overall mean AMBC observed in the current study was higher than the maximum recommended level of $2.0 \times 10^{6} \mathrm{cfu} / \mathrm{ml}$. A higher count also suggests that the milk has been contaminated by bacteria from different possible sources and it might be related to the overall sanitary conditions followed by the producers [25]. Such reports with high count may be due the contribution of insufficient premilking udder preparation, the use of poor quality water for cleaning without heat treatment and cleanness of the storage container and time. 
The mean value of aerobic mesophilic bacterial counts for milk samples taken from the milking bucket at farm level (8.02 $\log _{10} \mathrm{cfu} / \mathrm{ml}$ ) found in this study is higher than that of previous reports of Bekele and Bayleyegn in Addis Ababa (6.1 $\log _{10} \mathrm{cfu} /$ $\mathrm{ml}$ ), Lingathurai et al. in different locations of India (5.84 $\log _{10}$ $\mathrm{cfu} / \mathrm{ml}$ ) and Haile et al. in Hawassa (7.28 $\left.\log _{10} \mathrm{cfu} / \mathrm{ml}\right)$. Such differences might be attributed to the differences in the hygienic conditions such as the quality of cleaning water, milk containers, personal hygiene followed by the various producers.

The overall coliform count observed in the current study $(3.70$ $\log _{10} \mathrm{cfu} / \mathrm{ml}$ ) is lower than the value reported by Rahel in Wolayta zone (4.03 $\log _{10} \mathrm{cfu} / \mathrm{ml}$ ), Asaminew in Bahir Dar milk shed [4.84 $\log _{10} \mathrm{cfu} / \mathrm{ml}$ ], and Derese in West Shewa zone (4.49 $\log _{10} \mathrm{cfu} / \mathrm{ml}$ ). However, comparable result were reported by Mogessie and Fekadu and Mesfin from samples collected from udder milk (3.61 $\left.\log _{10} \mathrm{cfu} / \mathrm{ml}\right)$ and higher than the CC value for the udder milk samples $\left(1.0 \log _{10} \mathrm{cfu} / \mathrm{ml}\right)$ collected from dairy farm in Hawassa is reported by Haile et al. [26].

The present CC value for samples collected from milking bucket samples $\left(5.15 \log _{10} \mathrm{cfu} / \mathrm{ml}\right.$ ) was higher than the result obtained by Bekele and Bayleyegn in Addis Ababa (4.11 to 4.85 $\log _{10} \mathrm{cfu} / \mathrm{ml}$ ), Nanu et al. in India (3.2 $\left.\log _{10} \mathrm{cfu} / \mathrm{ml}\right)$. However, higher result from current study was observed by the report of Rai and Dawvedi, from India $\left(5.87 \log _{10} \mathrm{cfu} / \mathrm{ml}\right.$ ) and Zelalem et al. in central highlands of Ethiopia (6.57 $\log _{10} \mathrm{cfu} / \mathrm{ml}$ ), but comparable CC value were reported by Mogessie and Fekadu (5.4 $\log _{10} \mathrm{cfu} / \mathrm{ml}$ ) and Mesfin (6.57 $\log _{10} \mathrm{cfu} / \mathrm{ml}$ ) for milk samples taken from milk bucket of small holder dairy farms in three districts of Sidama zone [27]. The presence of high numbers of coliforms in milk indicates that the milk has been contaminated with fecal materials and it is an index of hygienic standard used in the production of milk, as unclean udder and teats can contribute to the presence of coliforms from a variety of sources such as poor farm hygiene, use of improperly washed milking equipment, unsanitary milking practices, contaminated water and cows with subclinical coliform mastitis can all lead to elevated coliform count in raw milk.

The higher values found in this study for both TABC and coliform counts as compared to the previous reports and EU and United States of America standards were attributed to the results of milk contamination emanating from the contamination of milk due to insufficient pre-milking udder preparation, insufficient cleaning of milkers' hands and milking utensils, use of poor quality and non-boiled water for cleaning of udder, milk equipment's and storage containers; additional handling of milk into different plastic containers and sieves may cause the contamination of milk higher [28].

Since as the number of plastic containers and sieves increased the chance of contamination is also increased and most plastic containers have characteristics that make them unsuitable for milk handling. Since plastic containers scratch easily and provide hiding places for bacteria during cleaning and sanitization and plastic containers are poor conductor of heat and hence will hinder effective sanitization by heat.

From the results of this study, it was found that the majority of the milk samples had higher bacterial count than the maximum recommended level, suggesting unfitness for human consumption especially for those with habit of consuming raw milk and milk products made from raw milk. Presence of high total bacterial load in raw milk indicates contamination possibly from lactating cows, milking equipment's, storage containers, unsatisfactory hygiene/sanitation practiced at farm level, unsuitable storage condition, unclean udder and/or teats, poor quality of water used for cleanliness and dirty hands of milkers.

Generally, it further indicates the level of hygiene practices in the whole milk production process and reflects the time elapsed since milking at ambient temperature. From the observed practices involved in the chain of milk production, handling, storage and consumption, during this study, the observed high bacterial count was expected. Therefore, based on these results and for the health safety of consumers, more food safety education should be given to producers, handlers and consumers.

\section{Conclusions and Recommendations}

Milk produced by small-holder dairy cow owners in Mersa kebele 02, Abiyot fre and Woldia kurkura of Mersa town were of poor quality, risky for human consumption and can be a potential source of milk-borne infections.. These results also showed that raw milk available to consumers has a high bacterial level of contamination. There were measurable increases in $\mathrm{AMBC}$ and coliform counts on the milk bucket. Based on the high level of counts found in the milk for consumption, one may suppose that this milk may pose a public health risk, and this suggests the need for more strict preventive measures. Majority of raw milk samples from the udder and bucket had higher AMBC and coliform counts, which was higher than the international acceptable limits. Hence, Milk produced dairy cow in Mersa town were of poor quality and can be a potential source of milk-borne infections. The level of awareness on the risk associated with consumption of raw milk is low. Therefore; awareness on the importance of hygienic production conditions and on zoonotic diseases should be done. Veterinarians and other concerned bodies have to play their roles in educating the general public health consequences associated with consuming raw milk and milk products. Routine assessment of milk quality produced by small-scale livestock keepers and consumed by the general public has to be taken to safeguard the public.

\section{Reference}

1. Abebe B, Zelalem Y, Ajebu N (2012) Hygienic and microbial quality of raw whole cow's milk produced in Ezhadistrict of the Gurage zone, Southern Ethiopia. Wudpecker J Agri Res 1: 459-465.

2. American Public Health Association (1992) Standard method for the examination of dairy products. 16th ed. APHA, Washington pp: 213-223.

3. Asaminew T (2007) Production, handling, traditional processing practices and quality of milk in Bahir Dar milk shed, MSc. Thesis. Haramaya University, Ethiopia. 
4. Ashenafi M, Beyene F (1994) Microbial load, microflora, and keeping quality of raw and pasteurized milk from a dairy farm Bull. Anim Hlth Prod Afr 42: 55-59.

5. Bekele G, Bayileyegn M (2000) Bacteriological quality of raw cow's milk from four dairy farms and a milk collection center in and Around Addis Ababa. Berliner and Mucnchener Tieraerztliche Wochenschrift 113: 276-278.

6. Bukuku JN (2013) Awareness of health risks as a result of consumption of raw milk in Arusha City and Meru District, Tanzania. Unpublished dissertation for award of MSc. degree at Sokoine University of Agriculture, Morogoro, Tanzania pp: 1-89.

7. Derese $T$ (2008) Present situation of urban and peri-urban milk production and quality of raw milk produced in West Shewa zone, Oromia Region. MSc. Thesis, Haramaya University, Ethiopia.

8. Fadaei A (2014) Bacteriological Quality of Raw Cow Milk in Shahrekord, Iran Veterinary World 7: 240-243.

9. Gilmour D (1999) Milking. In: Falvey L and Chantalakhana C (Eds): Smallholder Dairy in the Tropics. ILRI, Nairobi Kenya pp: 289-298.

10. Haile $W$, Zelalem Y, Yosef $T$ (2012) Hygienic practices and microbiological quality of raw milk produced under different farm size in Hawassa, Southern Ethiopia. Wudpecker J Agri Rev 4: 132-142.

11. Kashifa K, Ashfaque M, Iftikhar H, Masood A (2001) Bacteriological studies on raw milk supplied to Faisalabad city during summer month. University of agriculture. Pakistan Vet J 2: 21.

12. Lingathurai S, Vellathurail P, Vendan S, Anand A (2009) A comparative study on the microbiological and chemical composition of cow milk from different locations in Madurai, Tamil Nadu. India J Sci Technol 2: 51-54.

13. Mennane Z, Ouhssine M, Khedid K, Elyachioui M (2007) Hygienic quality of raw cow's milk feeding from domestic. Int J Agri Biol 9: 1560-8530.

14. Mesfin Z (2015) Hygienic practices, bacteriological quality of cow milk and its public health importance along the dairy value chain in Sidama high lands of southern Ethiopia Addis Ababa University, College of Veterinary Medicine and Agriculture, Ethiopia.

15. Ashenafi M (1990) Microbiological quality of ayib, a traditional Ethiopian cottage cheese. Int J Food Microbiol 10: $263-268$.

16. Mogessie A, Fekadu B (1993) Effect of container smoking and udder cleaning on microflora and keeping quality of raw milk from a dairy farm in Awassa. Tropical Sci 33: 368-378.

17. Mulugeta K, Million T (2013) The Bacteriological Safety and Antimicrobial Susceptibility of Bacteria Isolated from StreetVended White Lupin (LupinusAlbus) in Bahir Dar, Ethiopia. Ethiop J HIth Sci 23: 19-26.
18. Nanu E, Latha C, Sunil BP, Magna T, Vrinda KM (2007) Quality assurance and public health safety of raw milk at the production point. Am J Food Technol 2: 145-152.

19. Olatunji E, Ahmed I, ljah U (2009) Evaluation of microbial qualities of skimmed milk [nono] in Nasarawa State, Nigeria, Conference Proceeding, Proceeding of the 14th Annual Conference of Ani Sc Asso Nigeria.

20. Rahel N (2008) Traditional and improved milk and milk products handling practices and compositional and microbial quality of milk and buttermilk in Delbowatershed of WolaytaZone, MSc. Thesis. Department of Animal and Range Sciences, Hawassa College of Agriculture, School of Graduate Studies, Hawassa University, Ethiopia.

21. Rai AC, Dawvedi $F(1990)$ Bacteriological quality of market milk. Indian Dairyman, 101: 487-491.

22. Shija $F$ (2013) Assessment of milk handling practices and bacterial contaminations along the dairy value chain in Lushoto and Handeni districts in Tanga region. Unpublished dissertation for award of MSc. degree at Sokoine University of Agriculture, Morogoro, Tanzania pp 1-88.

23. Solomon M, Mulisa M, Yibeltal M, Desalegn G, Simenew K (2013) Bacteriological quality of bovine raw milk at selected dairy farms in Debre Zeit town, Ethiopia. Comp J Food Sci Tech Res 1: 1-8.

24. Soomro A, Arain M, Khaskheli M, Bhuto B (1996) Isolation of $E$. coli from raw milk and milk products in relation to public health sold under market conditions at Tandonjam. Pakistan J Nut 1: 151-152.

25. Swai ES, Schoonman L (2011) Microbial quality and associated health risks of raw milk marketed in the Tanga region of Tanzania. Asian Pac J Trop Biomed. 1: 217-222.

26. Yitaye A, Wurzinger M, Azage T, Zollitsch W (2009) Handling, processing and marketing of milk in the North western Ethiopian highlands. Livestock Res for Rural Dev 21: 97.

27. Yoseph M, Azage T, Alemu Y (2003) Evaluation of the general farm characteristics and dairy herd structure in urban and peri-urban dairy production system in AddisAbaba milkshed. Proceedings of the 10th annual conference of the Ethiopian Society of Animal Production (ESAP), held in Addis Ababa, Ethiopia, 22-24 August 2002. ESAP, Addis Ababa, Ethiopia. pp 139-144.

28. Zelalem Y, Yohannes G, Gizachew B, Alemu GW, Sendros D (2004) Major milk chemical composition and feed dry matter intake of multiparous Boran cows as affected by level of milk production under bucket feeding and partial suckling calf-rearing methods. Proceedings of the 11th annual conference of the Ethiopian Society of Animal Production (ESAP) held in Addis Ababa, Ethiopia pp: 397-402. 